\title{
European Communist Parties and Eurocommunism in the Cold War
}

\author{
Wolfgang MUELLER
}

The revolutions of 1989, the end of communist rule in Eastern Europe, and the overcoming of the Cold-War division of the continent have necessitated a reassessment of post-war European history. In the following years, the partial opening of former communist archives revitalized research on Eastern Europe and opened new perspectives which included the Eastern experience. ${ }^{1} \mathrm{New}$ attention was given to communist history which was perceived no longer as a solely Russian, but also as a Western European phenomenon. ${ }^{2}$

This themed issue aims at drawing attention to recent archival-based research on Cold-War communism in Europe and at integrating it into European history. Several European parties are presented in their transnational relations with external actors, communist and non-communist alike. The issue covers the entire period of the Cold War, ranging from post-war issues to the 1980s.

Since the emergence of the Communist International, the issue of "divided loyalty" of communists toward their respective country on one hand and Moscow as the ultimate arbiter in strategic issues on the other has sparked discussion. It shaped Western perceptions for the entire Cold-War history of European communism. In his article on "Togliatti, Tito and the Shadow of Moscow", Karlo Ruzicic-Kessler turns to the communist factor in post-war territorial disputes between Italy and Yugoslavia in the 1940s. The issue of the Italian-Yugoslav border, in particular Yugoslav claims on the border region around Trieste, created a crucial test for Italian communists under Palmiro Togliatti who struggled to combine Italian national interests with loyalty toward Soviet directives. Ruzicic-Kessler demonstrates how Togliatti and Yugoslav

1. E.g. G.P. MURASHKO et al. (eds), Vostochnaia Evropa v dokumentakh Rossiiskih arkhivov 19441953, Sibirskii khronograf, Moscow, 1997-98; T.V. VOLOKITINA et al. (eds), Sovetskii factor v Vostochnoi Evrope, Rosspen, Moscow, 1999-2002; J. ROTHSCHILD, Return to Diversity. A Political History of East Central Europe Since World War II, Oxford University Press, New York, 1993; I.T. BEREND, Central and Eastern Europe 1944-1993. Detour from the Periphery to the Periphery, Cambridge University Press, Cambridge, 1996; M. MAZOWER, Dark Continent: Europe's Twentieth Century, Lane, London, 1997; T. JUDT, A History of Europe Since 1945, Penguin, New York, 2005; T. SNYDER, Bloodlands: Europe between Hitler and Stalin, Basic Books, New York, 2010.

2. F. FURET, Le passé d'une illusion, Laffont, Paris, 1995; J. HOLZER, Der Kommunismus in Europa, Fischer, Frankfurt/Main, 1998; S. COURTOIS et al., Le livre noir du communisme, Laffont, Paris, 1999; R. PIPES, Communism: A History, Random House, New York, 2001; M. DREYFUS et al., Le siècle des communismes, Atelier, Paris, 2000; A. BROWN, The Rise and Fall of Communism, Vintage, London, 2009; J. PRIESTLAND, The Red Flag: A History of Communism, Grove Atlantic, New York, 2009; R. SERVICE, Comrades! Communism, a World History, Macmillan, London, 2009; D. SASSOON, One Hundred Years of Socialism: The West European Left in the Twentieth Century, Tauris, London, 2010; S. PONS, La rivoluzione globale: storia del comunismo internazionale, 1917-1991, Einaudi, Turin, 2012. 
leader Tito developed their strategies regarding the disputed region and attempted to persuade the Soviet leadership of their respective arguments.

Three years after Stalin's death, the twentieth congress of the Communist Party of the Soviet Union (CPSU) declared that communists might have the right to choose their own "national path". This did not mean that the Kremlin abandoned its leading role in world communism. Yet, diversity among and within communist parties grew, and new tendencies emerged in Eastern and Western European parties alike, such as in, e.g., Poland, Hungary, and Italy. Even after the Soviet military intervention in Hungary, some reformist tendencies lived on. Maximilian Graf draws our attention to one of these tendencies in the hitherto often neglected Communist Party of Austria by analysing "The Rise and Fall of 'Austro-Eurocommunism"” in the 1960s. While liberalizing tendencies were welcomed by some communists, they were watched with mistrust by others. East German communists took the lead in fighting reformers within the KPÖ who were perceived as violating the principle of loyalty toward the Soviet model. Graf argues for placing the Austrian reformist tendencies into the context of an early period of Eurocommunism, a movement that surfaced some years later among Western communists and advocated detaching Western communist parties from the Soviet model after the Warsaw-Pact crackdown on the Prague Spring of 1968.

Despite the East German SED's rigid stance in ideological issues, the party later sought lucrative commercial relations with Western European partners, as Francesco di Palma demonstrates. He analyses the "Contradictory Relationship" between East German communists and the most influential Eurocommunist parties, Italy's PCI and the French PCF, and he argues that, as East Germany consolidated national sovereignty during the 1970s, transnational relations gained in importance for the SED, even with Eurocommunists.

Eurocommunism embodied the hope of Western communists that their movement could be more democratic than policy in Eastern Europe implied and that it might even become fit for participation in government. In the West, however, Eurocommunist electoral successes in Italy $1975-76$ provoked similarly ambivalent reactions as among their Eastern comrades - although the PCI even attempted to demonstrate independence from Moscow by reducing anti-American declarations and launching a friendlier policy toward the United States. This happened, as Valentine Lomellini argues in "When Hopes Come to Naught", with the aim of improving communist chances for participation in government. While the PCI's overtures toward liberal commentators, scientists and political actors in the United States bore some fruit, the State Department in January 1978 clarified that US policy would not favour communist participation in government.

Not only in Washington, but also in other NATO capitals, Eurocommunism was perceived a threat to Western stability, as Nikolas Dörr reminds us in "NATO and Eurocommunism: The Fear of a Weakening of the Southern Flank". Eurocommunist electoral successes in member countries of the Alliance, such as Italy, France and Spain, which joined the Alliance in 1982, triggered Western fears of a Soviet "Trojan 
horse" within NATO. Here again the issue of divided loyalty of Western communists comes up. Dörr analyses threat perceptions in NATO countries as well as strategies for dealing with it by the Western alliance, the Federal Republic of Germany and the United States. Once the wave of Eurocommunist successes ended in the late 1970s, it was not seen as an existential threat to NATO anymore and the election of communist delegates, with Giorgio Napolitano among them, to the NATO Parliamentary Assembly in 1984 did not cause particular concern. However, it was only after the end of the Cold War that (former) communists played a leading role in Italian government again.

In accordance with the wishes of the journal's editorial board, this themed issue will be complemented by two non-topical essays. Michael J. Geary analyses the nexus between Ireland's negotiations on EEC membership in 1970-72 and the Community's Common Fisheries Policy which had been completed in 1970. The four applicants for membership, Britain, Denmark, Ireland and Norway, reacted negatively to the Policy. While the applicants as well as the Community were interested in successful membership negotiations, Dublin and Brussels "tried to outmanoeuvre each other on the CFP issue". In the last article of this issue on Western Germany's preferences regarding the freedom of movement provisions in the EEC's 1963 association agreement with Turkey, Matthias Mayer demonstrates how a sending country of labour migrants, Turkey, was able to press EEC states to support liberalization of immigration policies. Mayer argues that this was possible, because the domestic salience of immigration was low.

Wolfgang Mueller Österreichische Akademie der Wissenschaften, Wien Institut für Neuzeit- und Zeitgeschichtsforschung 


\section{Europäische Schriften}

Herausgegeben vom Institut für Europäische Politik

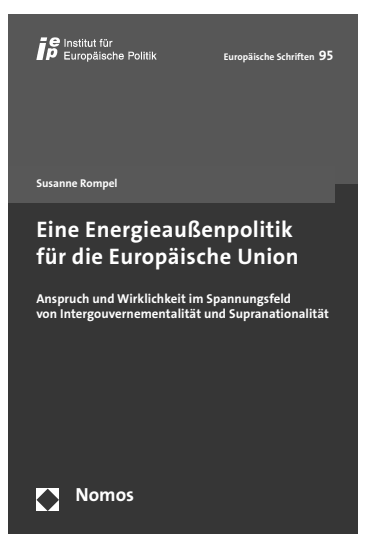

\section{Eine Energieaußenpolitik} für die Europäische Union

Anspruch und Wirklichkeit

Von Susanne Rompel

2015, Band 95, ca. 591 S., brosch., ca. 108,-€ ISBN 978-3-8487-1694-4

Erscheint ca. Januar 2015

www.nomos-shop.de/23946

Welche Voraussetzungen sind nötig, damit die Europäische Union in Energiefragen außenpolitisch handlungsfähig sein kann? Die Autorin verknüpft politikwissenschaftliche Theorie mit politischer Praxis und leistet mit pragmatischen Empfehlungen einen wichtigen Beitrag zur Entwicklung einer erfolgreichen EU-Energieaußenpolitik.

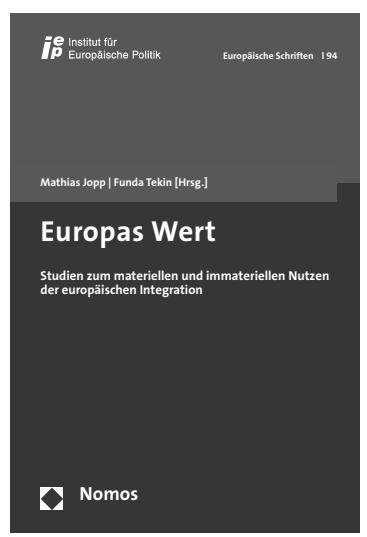

\section{Europas Wert}

Studien zum materiellen und immateriellen Nutzen der europäischen Integration Herausgegeben von Mathias Jopp und Funda Tekin 2014, Band 94, 255 S., brosch., 54,- $€$ ISBN 978-3-8487-1505-3 www.nomos-shop.de/23130

Europa ist weit mehr als nur die Ökonomie von Staaten und Banken. Für eine solche Betrachtung des Wertes Europas steht dieses Buch, in dem auch die Kosten der unvollständigen Integration - also eines (Nicht-Europas) - in Betracht gezogen werden. Der Band gibt allen, die sich in ihrer täglichen Arbeit mit europaskeptischen Ansichten auseinandersetzen müssen, Argumente für eine sachliche Diskussion an die Hand. 